\title{
X-Ray Spectrometry
}

WILEY

Microanalysis of Gothic mural paintings (15th Century) in Slovenia. Investigation of the technique used by the Masters

\begin{tabular}{|r|l|}
\hline Journal: & X-Ray Spectrometry \\
\hline Manuscript ID: & XRS-07-0086.R1 \\
\hline Wiley - Manuscript type: & Research Article \\
\hline Author: & 14-Jan-2008 \\
\hline Complete List of Authors: & $\begin{array}{l}\text { Kriznar, Anabelle; University of Ljubljana, faculty of Philosophy, } \\
\text { Dpt. of Art History } \\
\text { Ruiz Conde, Antonio; CSIC, ICMSE } \\
\text { Sánchez-Soto, Pedro Jose; CSIC, ICMSE }\end{array}$ \\
\hline Keywords: & $\begin{array}{l}\text { microanalysis, medieval mural paintings, pigments, mortars, SEM- } \\
\text { EDX, XRD }\end{array}$ \\
\hline &
\end{tabular}

\section{s) ScholarONE" \\ Manuscript Central}




\title{
Microanalysis of Gothic mural paintings (15th Century) in Slovenia. Investigation of the technique used by the Masters
}

\author{
A. $\operatorname{Kriznar}^{1}$, A. Ruiz-Conde ${ }^{2}$ and P. J. Sánchez-Soto ${ }^{2 *}$ \\ ${ }^{1}$ Department of Art History, Faculty of Philosophy, University of Ljubljana, Askerceva 2, \\ 1000, Ljubljana, Slovenia \\ 2 Instituto de Ciencia de Materiales de Sevilla (ICMSE), Centro Mixto Consejo Superior de \\ Investigaciones Científicas (CSIC)-Universidad de Sevilla, c/Américo Vespucio 49, 41092- \\ Parque científico y tecnológico Isla de la Cartuja '93, Sevilla, Spain
}

KEY WORDS: microanalysis, medieval mural painting, mortars, pigments, SEM-EDX, XRD 


\begin{abstract}
The present paper focus on an interdisciplinary research of Cultural Heritage concerning the microanalysis of Gothic mural paintings made during the 15th century in Slovenia. The samples were chosen from the churches of Crngrob (1453), Mirna (1463-65), Mevkuž (1465) and Mače (1467), attributed to two of the most important Gothic painters of that period of time: Master Bolfgang and Master of Mače. The chemical and phase composition of all the mortars was of interest, the number of their layers and the selection of the pigments. For this purpose, fragments of mural paintings were studied with several instrumental techniques: OM, SEM-EDX, XRD and FTIR. In early artworks, the mortar was made using a mixture of lime and more or less clean sand. Later, crushed lime-rock or marble instead of sand was added to lime. The pigments identified by EDX microanalysis of cross-sections previously studied by OM, are of earth or mineral origen. Therefore, they are durable in fresco and lime technique: lime white, yellow and red natural or burned ochres, green earth and azurite. The results confirmed the high technical quality of both painters and the relationships between the teacher and the disciple. Master Bolfgang and Master of Mače combine three basic techniques of mural painting: a fresco, a secco and lime technique. This kind of investigation and methodology allow us to know better the Central European Art and the Slovenian Art in the Adriatic zone, as well as the general map of European Art in the $14-15$ centuries.
\end{abstract}




\section{INTRODUCTION}

Mural or wall painting in a wide sense from Egyptian world, Roman Empire and Middle-Age, may be defined any painted design or composition applied directly to the surface of buildings and monuments. ${ }^{1-6}$ Ranging from simple decorative patterns to more complex figurative or even narratives schemes, mural paintings form integral components of the building or monument artwork. While some mural paintings can be quite simple in both artistic and technical point of view, the majority consist of a combination of materials applied on a succession of layers. There are some illustrative examples in the literature. ${ }^{1-11}$ The present research deals with the analysis of materials and techniques of mural paintings, used by the masters who worked in the second half of the 15 th century in the territory that today belongs to Slovenia. The research was made as an international collaboration in Cultural Heritage between Slovenia and Spain. The interdisciplinary approach to the subject was carried out by art historians, restorers, chemists and geologists working together. The Department of Art History at the University of Ljubljana (Slovenia) started a study on Gothic mural paintings of a monument at Selo, Prekmurje (NE Slovenia). ${ }^{7-9}$ This precedent research was in connection with the Central Europe painting, more exactly with the murals of around 1400, with particular attention of the so called "North-Styrian Dukes Workshop". 9 This Workshop was working during decades for the members of Habsburg Royal Family and their courts. Therefore, the masterpieces of Slovenia, Austria, Italy and Czchec Republic were compared using stylistic methods and the physical-chemical studies on selected samples were started. Later, this study was enhanced to the whole Slovenian territory, in order to get more precise information about techniques and materials used by medieval painters in today's Slovenia. ${ }^{10-14}$

Part of this investigation was dedicated to mural cycles in the churches of Crngrob (mural paintings dated in 1453), Mirna (1463-65), Mevkuž (1465) and Mače (1467), attributed to two of the most important Gothic painters of that period of time: Master Bolfgang and Master of Mače. They are both highly acknowledged for their quality in style and in technique of execution. ${ }^{7,8,11}$ The first one, whose name it is known from the inscription he left on the cycle of Crngrob, came to Slovenia from the North of Europe. In his paintings, he cut with the tradition of International Gothic Style and cultivated more realistic, late Gothic art expresion. ${ }^{7,8,15}$ His most beautiful cycle is found on the ceiling of Mirna's church (Fig. 1). The so-called Master of Mače was 
Bolfgang's disciple and he worked with him in Mevkuž (Fig. 2). He followed the teacher's style, but was much more lyric in his expression, what it is clearly seen in his best work: the mural cycle in the church of Mače (Fig. 3) that also gave him the auxiliary name.

The goals of the present research were to analyze and compare the composition of the supports (mortars) in all mentioned locations, the selection of pigments and binding media and the technique of Gothic mural paintings used by both Masters. It would be intended to distinguish possible differences in the painting technique and pigments used, as well as in the composition of mortars and wall supports. The analytical and phase composition of all the mortars is of interest, the number of layers and the selection of the pigments used by both Masters. The analytical investigations of samples coming from the Cultural Heritage bring much information on developments in technologies and on the propagation of culture, being of interest for conservation and protection of historic monuments in Europe. ${ }^{16}$ Some selected results are presented and discussed in this paper. It should be noted that the samples from the monuments were not studied up to now using techniques of materials characterization and analysis.

\section{MATERIALS AND METHODS}

Selected samples were obtained, in part, from several fragments of mural paintings including mortars. They dropped from the walls during the discovery and initial restoration works (performed in 1935) in Crngrob, being deposited at the Department of History, Faculty of Philosophy, University of Ljubljana (Slovenian Republic). ${ }^{8}$ However, it was also necessary to get more sample materials from other locations of both masters in situ to include them in the present investigation and to become a more general study. ${ }^{11}$ To achieve the goals of this research, tiny samples of mortars and pigments were carefully chosen and taken from the mural paintings after a precise exam de visu. Very significant differences considering the mortars as plaster supports of these mural Gothic paintings have been found, as it will be described later.

The scientific investigation of the Gothic mural painting samples was mainly based in the preparation of the cross-sections from the original small samples. ${ }^{17-23}$ This methodology allows to study the different layers of mortar as support and the painting itself. The samples were studied in form of elaborated cross-sections using a resin, previously polished, or in form of ground powders, depending on the laboratory 
procedures and instrumental techniques used, ${ }^{17,20,21,23,25}$ those are commonly applied in materials characterization: optical microscopy (OM), scanning electron microscopy (SEM) and energy dispersive X-ray spectroscopy (EDX) to carry out the sample microanalysis, Fourier Transform Infra-Red spectroscopy (FTIR) and X-Ray powder diffraction (XRD). At the time of this investigation work no XRF analysis was possible, although it would have been of great interest to use portable XRF equipment for the first analysis of the mural paintings directly in situ in the selected churches. This step would probably reduce the number of the necessary samples taken from the paintings. Only later on we had XRF equipment at hand, and just for a short time. We tried to use it in the small samples taken from the paintings, already analysed by other techniques. But the samples were too small to give any relevant results.

OM was carried out by means of a conventional reflected light microscope Nikon, model 115, with fibre optic illumination fitted to a Nikon Coolpix 5000 digital camera. Selected micrographs representative of the main observations of cross-section samples are presented here. SEM observations were undertaken with a JEOL JSM 5400 instrument. The cross-section samples were previously metallized with a thin layer of $\mathrm{Au}$ by sputtering. ${ }^{24}$ EDX microanalysis of these cross-section samples was performed under the SEM equipment using an Oxford Link analyser with $\mathrm{Si}(\mathrm{Li})$ detector, Be window, at $20 \mathrm{kV}$. For additional information concerning mortars, pigments and possible organic substances, FTIR spectra of selected zones in the cross-sections were obtained with a FTIR Nicolet instrument, model 510. In some cases, $1 \mathrm{mg}$ powdered sample and $400 \mathrm{mg} \mathrm{KBr}$ were mixed and ground, preparing pressed pellets used for the analysis by FTIR transmission spectroscopy. ${ }^{17,20,21,23}$ For the mortar analysis the best technique was the XRD. Selected samples were ground using an agate mortar and pestle. This very fine powder was studied by Siemens D-501 diffractometer, at $40 \mathrm{kV}$ and $20 \mathrm{~mA}$, with $\mathrm{CuK} \alpha$ Ni-filtered radiation and speed $0.5^{\circ}$ in $2 \theta$ per minute. $^{25}$

It is important to mention that this kind of analysis and materials characterization was not possible, at this time, in Slovenia due to a lack of adequate instrumental equipment, technical experts and methodology. This is a great difference in relation to other countries of the European Union, including Spain and, in particular, the ICMSE, being the origin of a Spanish-Slovenian Bilateral Cooperation. ${ }^{11-15}$ 


\section{RESULTS AND DISCUSSION}

\section{Mortars}

Mortar in ancient structures is a composite material which has exhibited excellent durability through time. ${ }^{4,6,26-28}$ It is constituted of a binder, such as lime $(\mathrm{CaO})$ and/or gypsum, and aggregates, such as sand or grit. The composition of mortars varies greatly and they are commonly divided into lime, gypsum and mixed ones, depending on the binding material. The most common one is lime mortar, in which slaked lime is used as a binder. It should be noted that the calcination of calcite rock (calcium carbonate, $\mathrm{CaCO}_{3}$ ) at $800-900{ }^{\circ} \mathrm{C}$ produces burnt lime (calcium oxide, $\mathrm{CaO}$ ) and, after cooling, the hydration process of lime yields the hydroxide $\mathrm{Ca}(\mathrm{OH})_{2}$ also known as slaked lime. After a carbonation process in air, the hydroxide in the mortar yields calcium carbonate again. Several authors have studied these simple but, at the same time, complicate chemical processes. For instance, Pires and Cruz. ${ }^{28}$ have summarized this process concerning the study of ancient mortars.

The examination of mortar samples in cross-sections by OM, as first step, and SEM and EDX microanalysis, as second step, allowed to study the composition of mural paintings, to determine if there is more than one layer of the composite mortar, how it was made (granulation, quantity, kind of sand, purity of lime) and if there exists a layer of lime that freshened up the mortar. The phase analysis of powdered and ground mortar samples by XRD allowed us to achieve a more complete and complementary information on the materials characterization of these mural paintings.

The observation of cross-sections by OM and SEM, the microanalysis by EDX (zones and point analysis) and the XRD results of the samples show an interesting change in the composition of mortars. In early works (Crngrob), Master Bolfgang employed mortars of lower quality, made of lime and more or less clean sand (Fig. 4a). The elaborated cross-sections permit to observe the calcite matrix and sand grains, of different colour, dimension and form. The reddish ones reveal the presence of iron oxides; the more transparent ones are of quartz, for example. The XRD analysis (Fig. 4b) confirmed that the mortars contain mostly calcite $\left(\mathrm{CaCO}_{3}\right)$ and quartz. In some samples, dolomite, feldspars and clay, as minor crystalline phases were also identified. These results were confirmed by a complementary EDX analysis in the cross-sections as observed by SEM. The spectra reveal $\mathrm{Ca}$ as the predominant element belonging to lime, while $\mathrm{Mg}, \mathrm{Al}, \mathrm{Si}, \mathrm{K}$ and $\mathrm{Fe}$ are present in lower quantity, representing different 
sand grains (Fig. 4c). Also some of these grains were analysed separately, showing small differences in their chemical composition, containing more or less of $\mathrm{Na}, \mathrm{Mg}, \mathrm{Al}$, $\mathrm{K}, \mathrm{Fe}$. The quartz grains were identified by containing only Si.

In posterior artworks (Mirna, Mevkuž), Master Bolfgang opted for a mixture of lime and crashed marble or calcite (lime-rock) instead of sand to prepare the painting surface. This change in materials was produced probably due to a contact with Italian fresco tradition. In this kind of plasters the presence of calcite has two origins: a) as a binder $^{28}$ and b) as an aggregate. This kind of mortar is whiter and more consistent as the first one that he employed, and therefore also better as a painting surface. The difference is well observed from the selected cross-sections from both localities (Figs. 5a, 6a), where white, slightly transparent grains are mixed with white lime. The XRD analyses show the very clean Mirna mortar (Fig. 5b), made only of calcite $\left(\mathrm{CaCO}_{3}\right)$ and dolomite $\left(\mathrm{CaMg}\left(\mathrm{CO}_{3}\right)_{2}\right)$, while in the Mevkuž mortar (Fig. 6b) a small quantity of quartz is appreciated as well. Weddellite $\left(\mathrm{C}_{2} \mathrm{CaO}_{4} \cdot 2 \mathrm{H}_{2} \mathrm{O}\right)$ peaks reveal some biological action/deterioration process on the mortar. In both cases no additional EDX analysis was realized as it was considered irrelevant.

Master of Mače, nevertheless, returned to the initial lime and sand mixture. His mural paintings decorate not only the inner church walls, but we also find some scenes on the outer southern wall. Already by the naked eye we could appreciate that the outer mortar is rougher, made of bigger sand grains and less lime as the inner one. Both components were mixed with less precision, as well. The selected cross-section from the outer mortar (Fig. 7a) shows abundant small sand grains of different reddish and brownish colours, mixed with white lime. On the other hand, in the cross-section from the inner mortar (Fig. 7b) we observe less send grains dispersed in more lime. Both mortars were analysed by XRD. The results reveal that the mortar from Mače is made of calcite $\left(\mathrm{CaCo}_{3}\right)$, dolomite $\left(\mathrm{CaMg}\left(\mathrm{CO}_{3}\right)_{2}\right)$ and quartz $\left(\mathrm{SiO}_{2}\right)$. The basic difference between the inner (Fig. 7c) and the outer one (Fig. 7d) is that the first one contains more relative proportion of dolomite, while the second one has more relative proportion of calcite and is richer in quartz, therefore contains more sand. Also in these cases no additional EDX analysis was considered necessary. In all Mače mortars there is less sand as in the Crngrob plaster. The lack of feldspars and clays reveal that the sand used in this location is much cleaner than the one applied in Crngrob.

\section{Pigments and binding media}


Fresco is an ancient technique of painting on walls. ${ }^{1-6,21,29,30,31}$ The true fresco entails the application of natural inorganic pigments dispersed in water to fresh, damp mortar. The identification of pigments from mural paintings, presented in this work, was realised firstly by examination of selected samples in cross-sections by OM, and secondly by SEM-EDX and FTIR. The cross-sections allowed us to study the composition of mural paintings, the number of colour layers applied, their sequence and thickness as well as the painting technique (a fresco or a secco), reminding of possible differences between the artist's procedure. OM is a useful way to achieve a basic characterization of pigments used in mural paintings. Nevertheless, the profound chemical analysis was run by SEM-EDX. These results offered us the major part of the information about the pigments applied in each location. The samples were analysed in the form of cross-sections or as powder. As a complementary technique, we applied FTIR to get the information about the chemical compounds in the colours. This technique is useful especially to identify possible organic materials, what is not an option with other instrumental techniques we used. For XRD and XRF analysis we had not sufficient quantity of samples.

The general results by all these techniques have shown that the pigments in all these mural cycles are of natural inorganic origin, mostly earths and minerals. They all are optimal for painting in the technique a fresco and in lime technique: 4,5,21,30,31,33,34 lime white $\left[\mathrm{Ca}(\mathrm{OH})_{2}\right.$ or $\left.\mathrm{CaCO}_{3}\right]$, yellow and red natural or burned ochres $\left[\mathrm{Fe}_{2} \mathrm{O}_{3}\right]$ and the mineral azurite, a basic copper carbonate $\left[2 \mathrm{CuCO}_{3} \mathrm{Cu}(\mathrm{OH})_{2}\right]$. Surprisingly, no malachite, copper pigment of green colour, with chemical composition $\mathrm{CuCO}_{3} \mathrm{Cu}(\mathrm{OH})_{2}$, was found. However, it should be emphasized that pigments from artworks are rarely pure, have different particle sizes and they can be mixed with other pigments or additives (organics and/or inorganics), to provide the artist's desired paint colour. $^{4,5,11,17,20,21,26,30,33}$

Fig. 8 shows selected optical micrographs of cross-section samples of mural paintings revealing the violet colour made as a mixture of red ochre and white lime (a) and orange colour obtained by a mixture of yellow and red ochre (c). These samples of mural paintings correspond to the churches of Mače and Mirna, respectively. The EDX spectrum show, in the first case (b), high peaks of $\mathrm{Ca}$ (lime) and $\mathrm{Fe}$ (red ochre), together with lower presence of $\mathrm{Mg}, \mathrm{Al}$ and $\mathrm{Si}$, belonging to the earth pigment as well. In the second case (d) the EDX spectra reveals the higher presence of Fe, coming from both ochres, while Ca corresponds to lime. Fig. 9 shows selected optical micrograph of 
cross-section sample of mural painting from the church of Mevkuž revealing white lime, yellow ochre, green earth and red ochre. Each colour layer was analysed by EDX. The spectrum of the upper red layer shows peaks relatively high intensity of $\mathrm{Fe}$, as it was expected, belonging to iron oxides, responsible for the red colour. Peaks of $\mathrm{Mg}, \mathrm{Al}$ and $\mathrm{Si}$ are lower in intensity and present traces in the earth pigment. The spectrum of the green layer, on the contrary, shows peaks of Si of higher intensity, the typical chemical elements for green earth, while $\mathrm{Mg}, \mathrm{Al}, \mathrm{K}, \mathrm{Fe}$ are minor elements. $\mathrm{Ca}$ is the predominant element, coming from lime. In the yellow layer the peaks of all these elements are of low intensity, but Fe is still the most characteristic one. In the micrograph of the cross-section of the sample from Mače we see a nice example of blue pigment (Fig. 10). The EDX spectrum identifies the pigment as azurite by X-ray peaks of high intensity of $\mathrm{Cu}$. Punctual zones of azurite particles appear with some kind of chemical transformation. The detection of chlore by EDX can be associated to basic copper chlorides produced by alteration of basic copper carbonate by reaction with chloride salts. The changes of blue parts into green colour, observed on the mural paintings in situ suggest that there must have been azurite altered by chemical processes in the presence of humidity to paratacamite $\left[\mathrm{Cu}_{2}(\mathrm{OH})_{3} \mathrm{Cl}\right] \cdot{ }^{17,18,21,30,33}$ However, XRD examination of these samples was not possible at this time because powdered samples were not available. Consequently, the phase analysis of pigments is based on results provided by OM, SEM-EDX and FTIR. According to Barba et al., ${ }^{35}$ to characterise ceramic pigments it is necessary to determine pigment phase and chemical composition, in addition to other properties (pigment quality, pigment additives, etc.). But this is only possible when pure pigments (synthesized as powders or reference materials) can be analysed. It is not the procedure when the pigments have been used in mural paintings and these kinds of samples of Cultural Heritage must to be studied in cross-sections. ${ }^{35}$

In some places of these mural paintings, lead pigments, such as lead-white (mineral phase is cerussite and/or hydrocerussite, a basic lead carbonate) can be found, although they have mostly darkened due to various chemical changes taking place by aging. They might belong to some restoration work and, therefore, are not attributed to both original Masters' palette.

The binding media for all these pigments is mostly inorganic: the lime from mortars or lime-water added to the pigments. Possible organic bindings were not discovered even using the FTIR technique. These organic additives were possibly used in such a small amounts that it is very difficult to identify them by IR spectroscopy. 
Besides this, after a long period of time organic substances (in many cases) can disappear because of the nature of the chemical composition and they can therefore not be determined. ${ }^{4,18,21,30,31}$ FTIR results, however, revealed inorganic phases such as carbonates and silicates previously detected by XRD and SEM-EDX. Thus, IR bands detected at 2516, 1795, 1480 (very strong), 1082 and $795 \mathrm{~cm}^{-1}$ are attributed to carbonates (calcite); IR bands centred at 1426 (very strong), 1170, 876, 692 and $459 \mathrm{~cm}^{-}$

${ }^{1}$ are associated to the presence of silica (as quartz) and silicates. ${ }^{11,13,21,23}$ This is an important confirmation of EDX microanalysis of pigments, because the FTIR spectra detected that the binding medium for pigments was lime from the fresh mortar and also revealed the earth minerals with silicate origin of some pigments, in particular green.

\section{Technique of execution of the mural paintings}

Master Bolfgang anf Master of Mače combined techniques a fresco, a secco and lime-wash, as confirmed by the results of microanalysis. By the true fresco, it is clearly seen by microscopic observation on the selected cross-sections presented here that there is not a defined line between the mortar and the colour layer (Fig 8c). The pigment layer shows a colour gradient resulting from the diffusion of the lime from the fresh mortar into the pigment during the work painting, as an analogous way of interaction of pigments and glazes during firing of glazed ceramics. ${ }^{36}$ On the other hand, lime-wash is distinguished as a compacted white layer between the mortar and the colour (Fig. 11). If the colours are painted already on the dry mortar or lime-wash, the border line between them can be clearly seen (Fig. 9a, 11). The results show that both masters used a combination of all three basic techniques of mural painting, starting on a fresh mortar and proceeding in lime technique or on the dry mortar to finish the work. Both painters are also very similar in choosing the pigments and in the manner of constructing the colour layers. In general, the painting procedure found in all analysed monuments is typical of North Europe: one or two layer of mortar with a fine layer of lime, where it is necessary. In the present case, the work on the fresh mortar could not be always finished in one giornatta because it started to dry and did not bind the pigments sufficiently anymore. That is why it has been found in some samples examined by OM and SEM a layer of lime wash (slaked lime) to freshen up the drying surface in some places. If the drying mortar was of poor quality (not enough lime). its binding strength was even weaker and a bigger part of the painting had to be finished a secco, especially draperies, 
faces and final details. In this case, the mural paintings are in worse condition after time as compared with those performed a fresco, and colour layers are falling off. However, all these results showed the high technical quality and high technical execution of both painters, and confirmed the relationships between Master and disciple.

\section{CONCLUSIONS}

This kind of microanalysis by EDX and materials characterization using OM, SEM, XRD and FTIR of mortars and pigments was not possible, at that time, in Slovenia due to a lack of adequate instrumental equipment and technical experts. This was the origin of a Spanish-Slovenian Bilateral Cooperation to study the historical mural paintings in Slovenian territory by an interdisciplinary approach, highlighting the relevance of scientific investigations in this field other than the art-historical, stylistic point of view. Thus, it is a clear example of how scientific and technical investigations can complement art historical research.

The information provided by this research about the composition of the mortars, the pigments used and the construction of single painting, or technique of execution of the mural paintings by Master Bolfgang anf Master of Mače, will be of great use and valuable interest. Although non-destructive analysis was the premise to conduct the present reasearch, samples were prepared from the mural paintings because they were available at that time. The analyses presented in this paper have been performed using the microscopic examination by OM of prepared and polished cross-sections, obtained from mural-painting samples, and subsequent application of EDX microanalysis after examination of selected preparations by SEM. Furthermore, XRD and FTIR have been used as complementary techniques of phase analysis and, the last one, to search the presence of organic compounds.

For instance, it has been concluded that Master Bolfgang used in his early work mortars of lower quality, made of lime and sand. Later, he started to apply a mixture of lime and crashed marble or calcite (lime-rock) instead of sand. In this way, he produced an improved support material for painting works, because this kind of mortar is whiter and more consistent as compared with the first one that he used, and therefore more convenient as a painting surface. Master of Mače followed using again the more common mixture of lime and sand. However, all these results confirmed the high 
technical quality of both painters and the relationships between Master and disciple. The microanalysis by EDX has allowed to identify the main pigments used by both Masters of natural inorganic origin: yellow and red natural or burned ochres, green earth, azurite, lime white and, in some places of these mural paintings, lead pigments, such as leadwhite have been identified. The mineral pigment malachite was not found in zones of green colour. The only binding media identified was the lime from mortar. No organic bindings could have been confirmed, although some dense colour layers in several cross-sections lead towards the conclusion that there was used some unidentified organic substance. Both masters used a combination of a fresco, a secco and lime technique and have constructed the painting layers in a similar way.

The present results are useful for the understanding of the technology of historic monuments in Slovenia and conservation of its Cultural Heritage, being interesting to plan some further conservation and restoration proceedings of the mural paintings at the churches of Crngrob, Mirna, Mevkuž and Mače. Furthermore, the present investigation and its methodology approach allow knowing better the Central European Art and the Slovenian Art in the Adriatic zone, as well as the general map of European Art in the 14-15 th centuries.

\section{Acknowledgements}

The authors acknowledge the financial support of Research Project MAT2002-02549, in part financed with Feder founds, Spanish-Slovenian 2004-2005 Bilateral Cooperation Project and Research Group TEP 204 (Junta de Andalusia). The support of CSIC Thematic Network on Cultural Heritage is also acknowledged. The authors want to dedicate this work to Prof. Dr. Janez Höfler, now retired, for his contribution in artwork studies in Slovenia and for the advisory in this research. 


\section{REFERENCES}

1. García Ramos G, Justo A, Abad Casal L. Archivo Español de Arqueología. 1976, 49: 141.

2. Pinilla E, García Ramos G. Pinturas medievales de La Rábida. Su conservación. Estudio físico-químico y mineralógico de muestras de pintura medieval de La Rábida (Huelva). Diputación de Huelva: Huelva 1976.

3. García Ramos G, Linares López MD, Abad Casal L. Archivo Español de Arqueología. 1978, 50-51: 295.

4. Mora P, Mora L, Philipot P. La conservazione delle Pitture Murali. Editrice Compositori: Bologna 2001.

5. Serchi M. (ed). Cennino Cennini: Il Libro dell'Arte. Felice Le Monnier: Firenze 1999.

6. Anastasiou M, Hasapis Th, Zorba T, Pavlidou E, Chrissafis K, Paraskevopoulos KM.

J. Thermal Anal. C. 2006, 84: 27.

7. Höfler J. Srednjeveske freske v Sloveniji. Gorenjska. I. Družina: Ljubljana 1996.

8. Höfler J. Srednjeveske freske v Sloveniji. Okolica Ljubljane z Notranjsko, Dolenjsko in Belo krajino. III. Družina: Ljubljana 2001.

9. Križnar A. The youngest layer of mural painting in Selo in Prekmurje. Zbornik Soboskega muzeja. 2001; VI: 7-25.

10. Križnar A. The influence of southern-tyrol art on the work of 'northstyrian duke workshop' in St. Ruprecht and in St. Lorentz in the valley of the river Mürz in the Northern Styria. ZUZ, n.v. 2002; 38: 55-78.

11. Križnar A. Slog in tehnika srednjeveskega stenskega slikarstva na Slovenskem. Filozofska fakulteta Univerze v Ljubljani, Založba ZRC SAZU: Ljubljana 2006.

12. Križnar A, Höfler J, Sánchez-Soto PJ. Cuadernos de Restauración, 2004, 5: 83-88.

13. Križnar A, Höfler J, Avilés MA, Jiménez E, Ruiz-Conde A, Sánchez-Soto PJ. Comunication presented at the 5 th Meeting of Spanish Cultural Heritage Network of CSIC, Madrid, 2004.

14. Križnar A, Ruiz-Conde, Sánchez-Soto PJ. Johannes Aquila and the technique of Gothic mural paintings (14 th century). In Heritage, Weathering and Conservation (R. Fort et al., eds.), Taylor \& Francis Group: London 2006: 867-872.

15. Križnar A, Höffler J, Ruiz-Conde A, Sánchez-Soto PJ. Bol. Soc. Esp. Ceram. V. 2007, 46: 76. 
16. Cassar M, Brimblecombe P, Nixon T, Price C, Sabbioni C, Sáiz-Jiménez C, Van Balen K. Sustainable solutions in the conservation and protection of historic monuments and archaeologic remains: a critical assessment of European research needs. In Air Pollution and Cultural Heritage (C. Sáiz-Jiménez, ed.). Balkema Publishers: Leiden, 2004: 249-261.

17. Matteini M, Moles A. Ciencia y Restauración: Método de investigación. IAPH, Nerea: Sevilla 1984.

18. Matteini M, Moles A. La chimica nel restauro. I materiali dell'arte pittorica. Nardini: Roma 1989.

19. Tsang JS, Cunningham RH. J. Am. Inst. Conserv. 1991; 30: 163.

20. Palazzi A, Analisi chimica per l'arte e il restauro: Principi, tecniche, applicazzioni. Nardini Editoriale: Fiesole 1997.

21. Gómez ML. La restauración: Examen científico aplicado a la conservación de obras de arte. Instituto del Patrimonio Histórico Español, Cátedra: Madrid 2000.

22. Jiménez Roca E. Estratigrafías: aspectos prácticos del análisis de estratos en obras del Patrimonio Histórico y Cultural.In Técnicas instrumentales y su aplicación al estudio del Patrimonio Histórico y Cultural. Gabinete de Formación del CSIC: Sevilla $2002 ; 65$.

23. Janssens K, Van Grieten R (eds). Non-destructive microanalysis of Cultural Heritage materials, Elsevier: Amsterdam 2004; 800-XXX.

24. Freestone IC, Middleton AP. Miner. Magazine 1987; 51: 21.

25. Ruiz-Conde A. Difracción y fluorescencia de rayos X. In Aplicación de técnicas instrumentales al estudio de materiales cerámicos y vítreos del Patrimonio Cultural. Gabinete de Formación del CSIC: Sevilla, 2003; 41.

26. Lambert JB. Traces of the Past: Unraveling the Secrets of Archaeology Through Chemistry. Perseus Books: Cambridge (Massachussets, USA) 1998.

27. Biscontin G, Birelli MP, Zendri E. J. Cult. Heritage. 2002; 3: 31.

28. Pires J, Cruz AJ. J. Therm. Anal. C. 2007; 87: 411.

29. Taft W.S. Mater. Res. Soc. Bull. 1996; 21: 18.

30. Brachert T. Lexicon historischer Maltechniken Quellen-Handwerk-TechnologieAlchemie. Callwey Verlag: Munchen 2001.

31. Mairinger F. Naturwissenschaftliche Untersuchungen an Wandmalereien,

Historische Technologie und Konservierung von Wandmalerei. Verlag Paul Haupt:

Bern/Sttugart 1985. 
32. Granger F (ed). Vitruvius: On Architecture. I-II. Mass: London, Cambridge 19551956.

33. West Fitzhugh E, Feller R, Roy A (eds). Artists' pigments. A Handbook of their history and characterisation. I-IV. National Gallery of Art: Washington, Oxford University Press: New York, Oxford 1997

34. Eastaugh N, Walsh V. Chaplin T. and Sidall R., Pigment Compendium: A Dictionary of Historical Pigments. Elsevier Butterworth-Heinemann: Oxford/ Burlington 2004.

35. Barba A, Gazulla MF, Gómez MP, Orduña M. X-ray Spectrom. 2006; 35: 383-389.

36. Roldán C, Coll J, Ferrero JL, Juanes D. X-ray Spectrom. 2004; 33: 28-32. 


\section{FIGURE CAPTIONS}

Figure 1. Mural paintings of the church at Mirna: the ceiling of presbytery.

Figure 2. Mural paintings of the church at Mevkuž: triumphal arch and the nave.

Figure 3. Mural paintings of the church of Mače: north wall of the nave and part of the triumphal arch.

Figure 4. Selected optical micrograph of cross-section sample of mural painting from Crngrob (a) with corresponding XRD diagram (b) and EDX spectrum (c).

Figure 5. Selected optical micrograph of cross-section sample of mural painting from Mirna (a) with corresponding XRD diagram (b).

Figure 6. Selected optical micrograph of cross-section sample of mural painting from Mevkuž (a) with corresponding XRD diagram (b).

Figure 7. Selected optical micrograph of cross-section sample of mural painting from Mače. The outer mortar (a) with corresponding XRD diagram (b) and the inner mortar (c) with the corresponding XRD diagram (d).

Figure 8. Selected optical micrographs of cross-section samples of mural paintings showing the violet colour made as a mixture of red ochre and white lime from Mače (a) with the corresponding EDX spectrum (b) and orange colour obtained by a mixture of yellow and red ochre from Mirna (c) with the corresponding EDX spectrum (d).

Figure 9. Selected optical micrograph of cross-section sample of mural painting from Mevkuž (a) with corresponding EDX spectra showing white lime (b), yellow ochre (c), green earth (d) and red ochre (e).

Figure 10. Selected optical micrographs of cross-section sample of mural painting from Mače (a) with corresponding EDX spectrum showing azurite.

Figure 11. Selected optical micrograph of cross-section sample of mural painting in Crngrob showing the combination of lime technique and painting on a dry surface ( $a$ secco). 


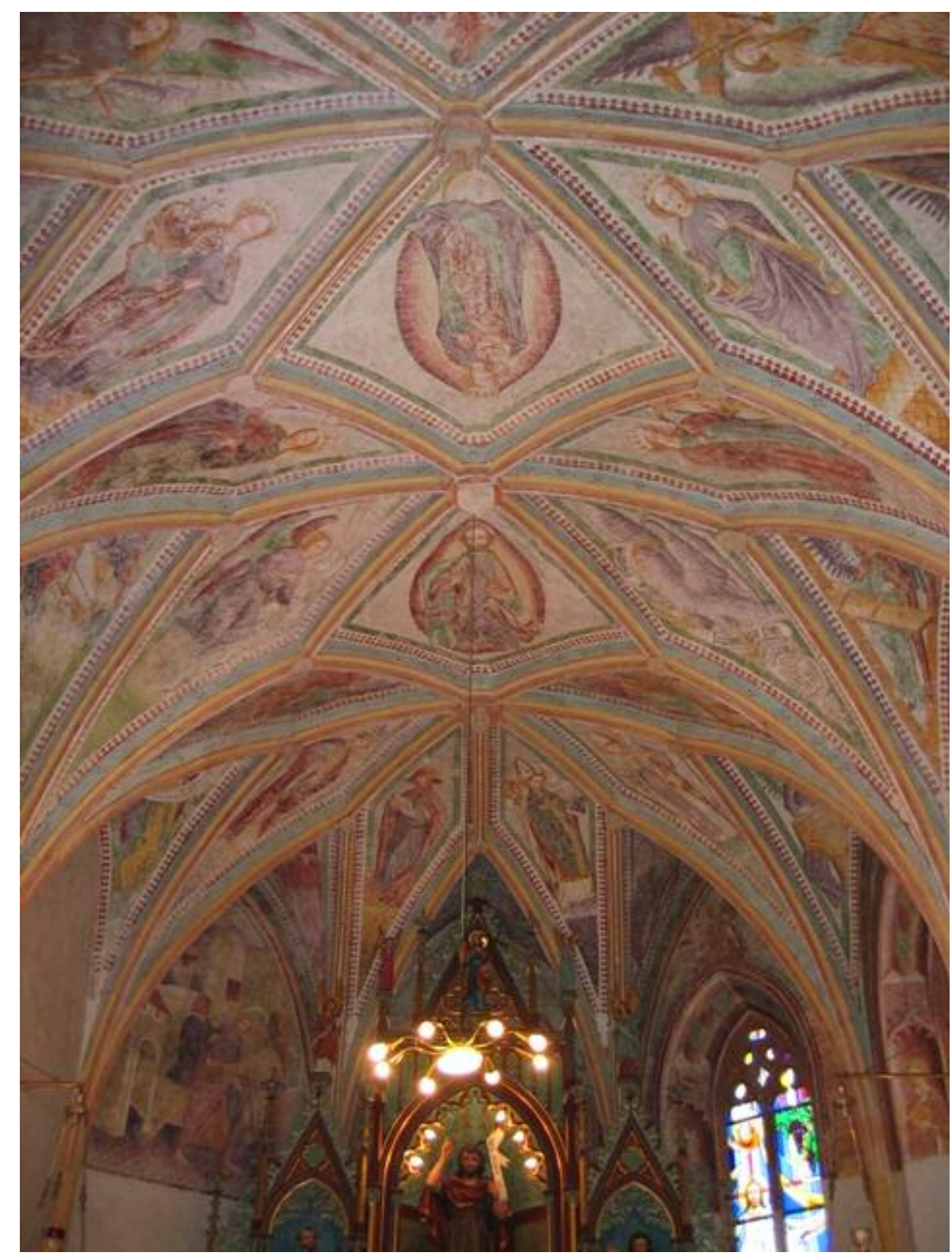

Figure 1. Mural paintings of the church at Mirna: the ceiling of presbytery. $127 \times 169 \mathrm{~mm}$ (96 x 96 DPI) 


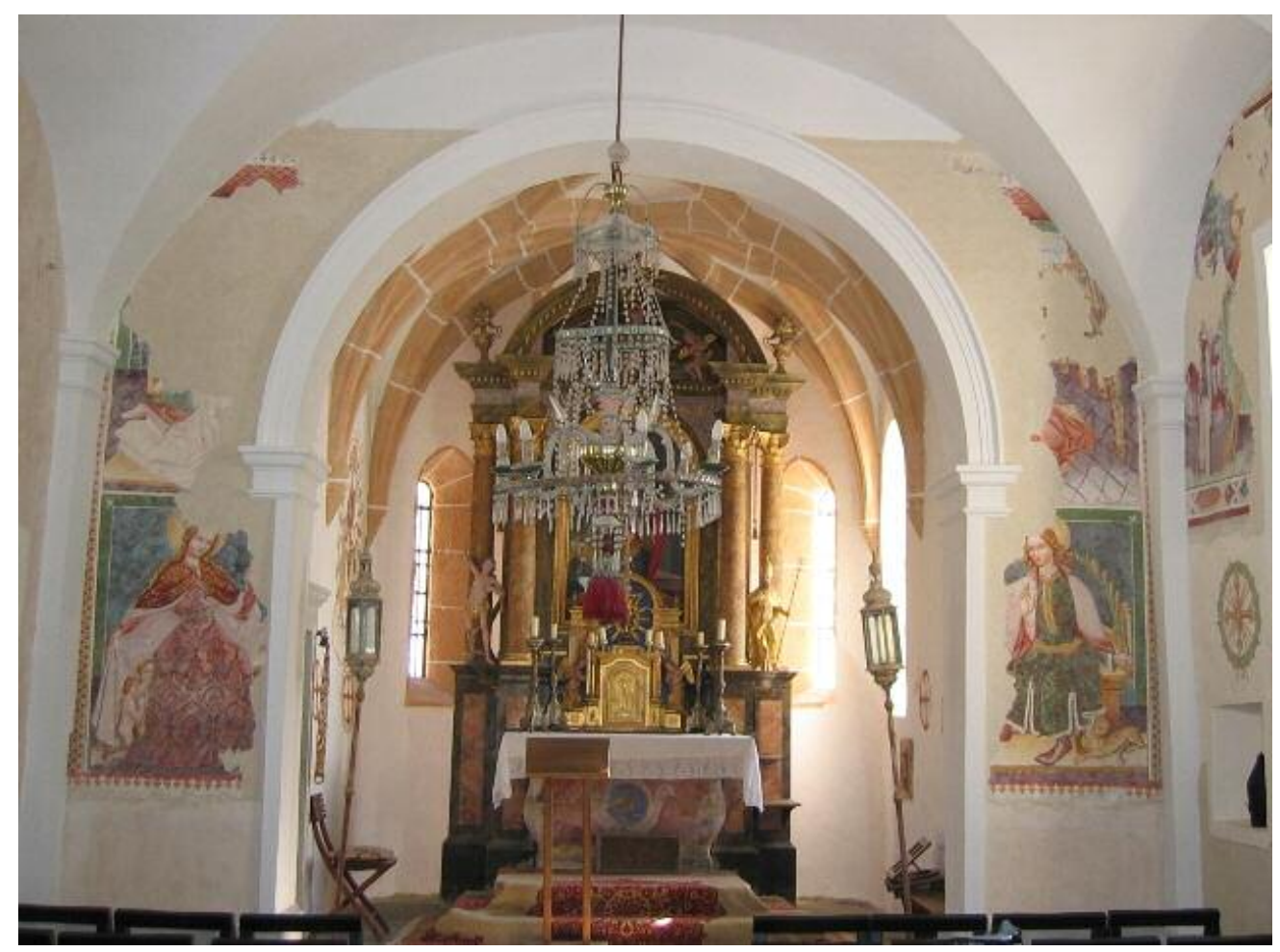

Figure 2. Mural paintings of the church at Mevku : triumphal arch and the nave. $169 \times 125 \mathrm{~mm}(96 \times 96 \mathrm{DPI})$ 


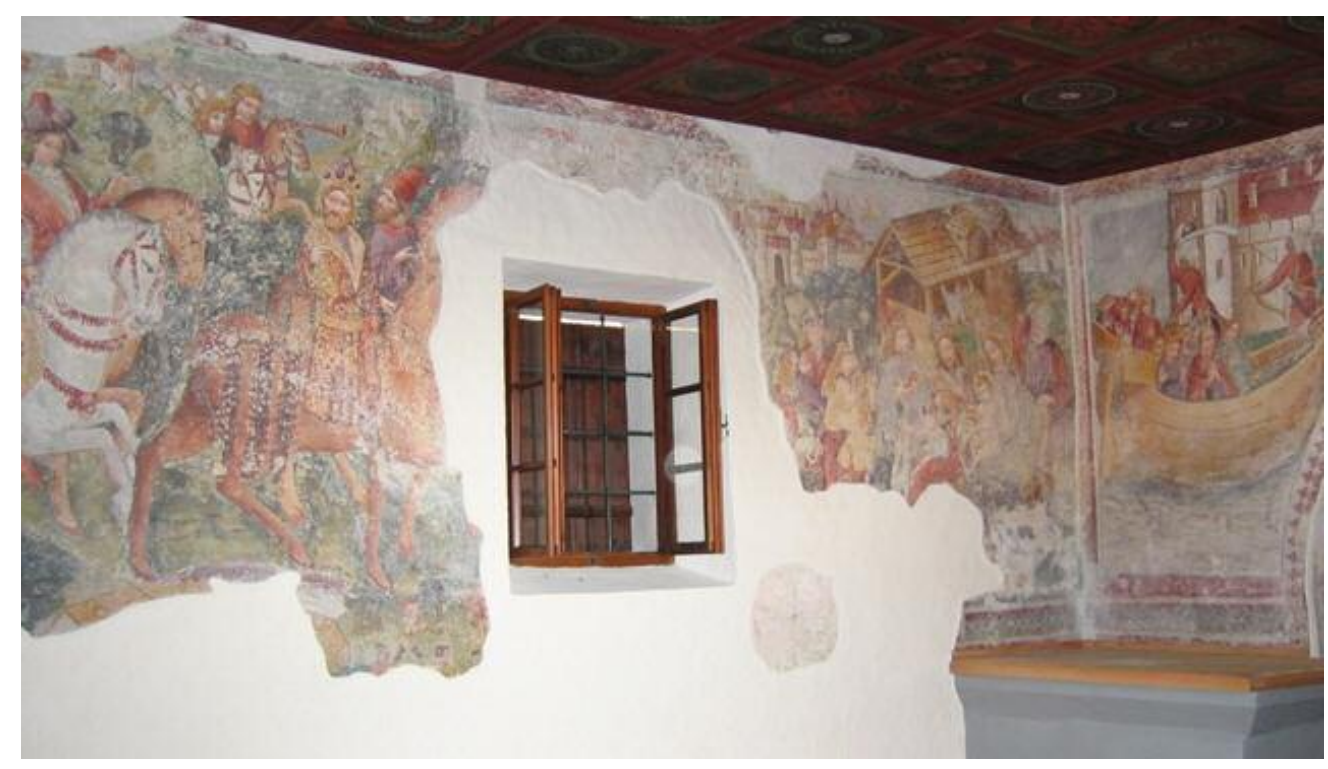

Figure 3. Mural paintings of the church of Mače: north wall of the nave and part of the triumphal arch. $169 \times 96 \mathrm{~mm}(96 \times 96 \mathrm{DPI})$ 


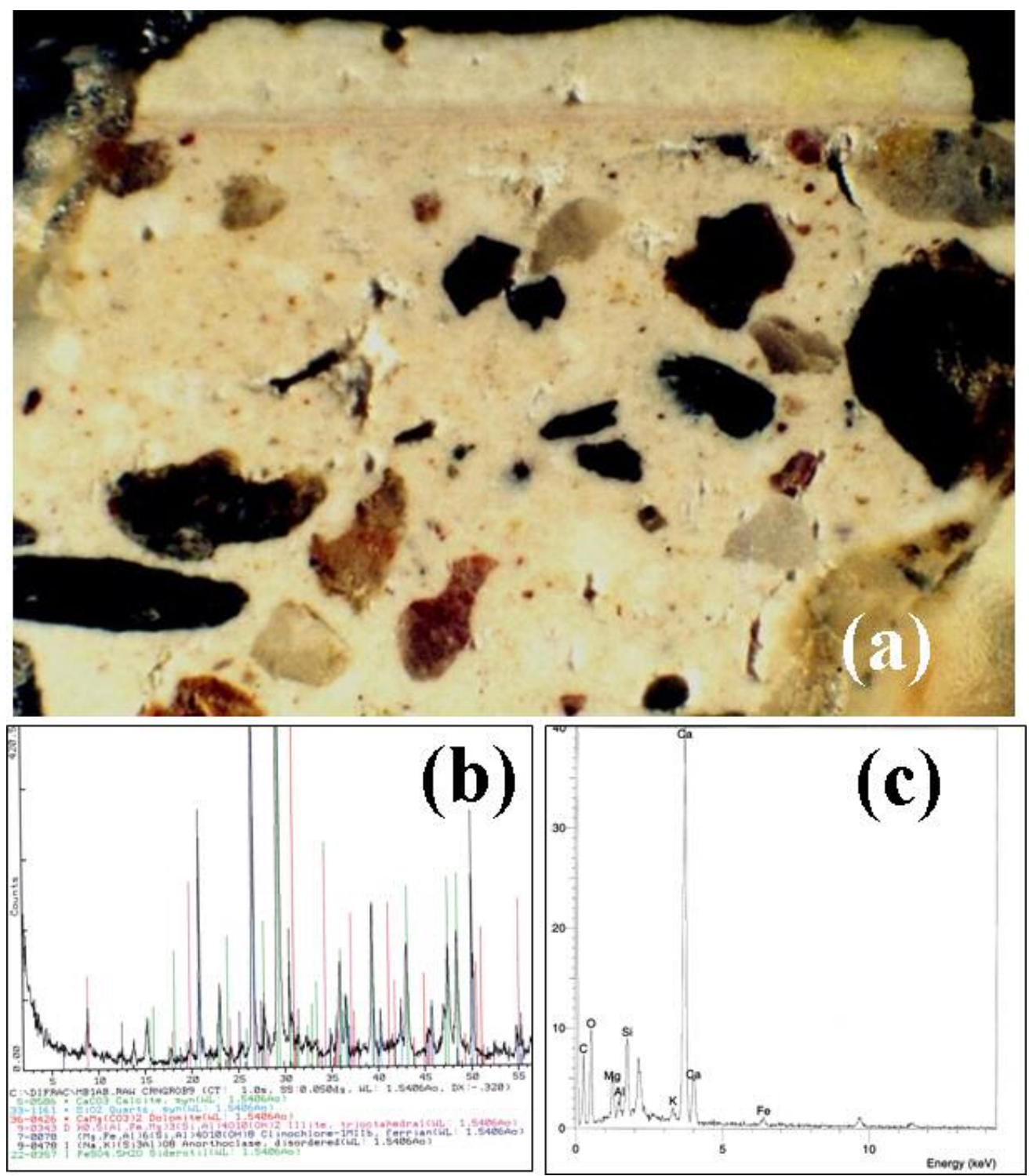

Selected optical micrograph of cross-section sample of mural painting from Crngrob (a) with corresponding XRD diagram (b) and EDX spectrum (c). 

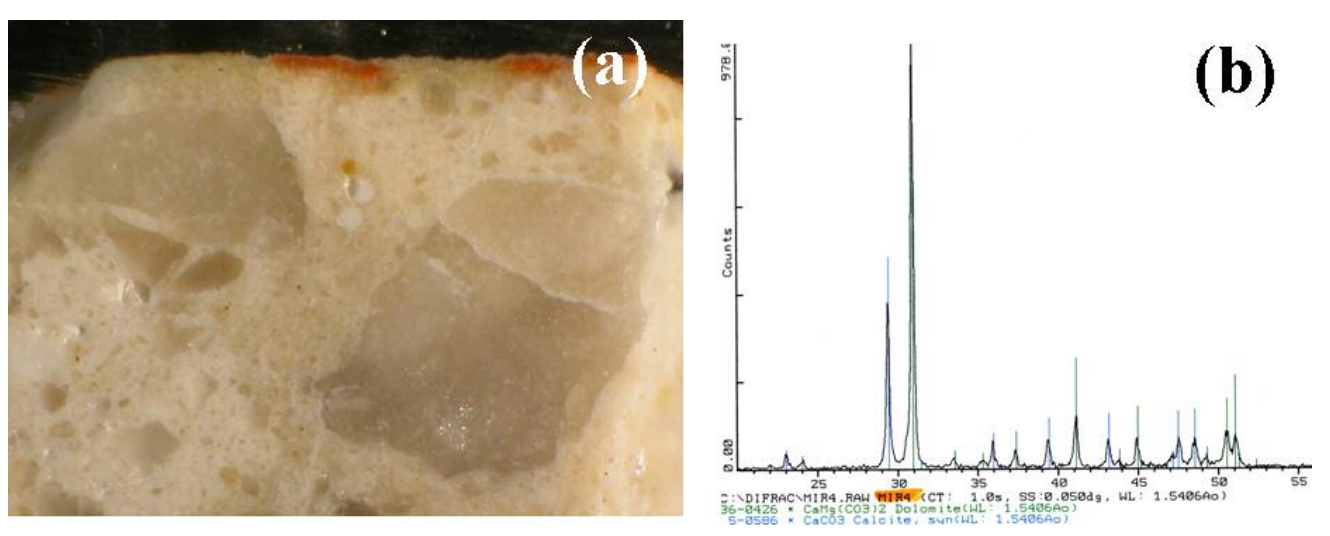

Selected optical micrograph of cross-section sample of mural painting from Mirna (a) with corresponding XRD diagram (b). 

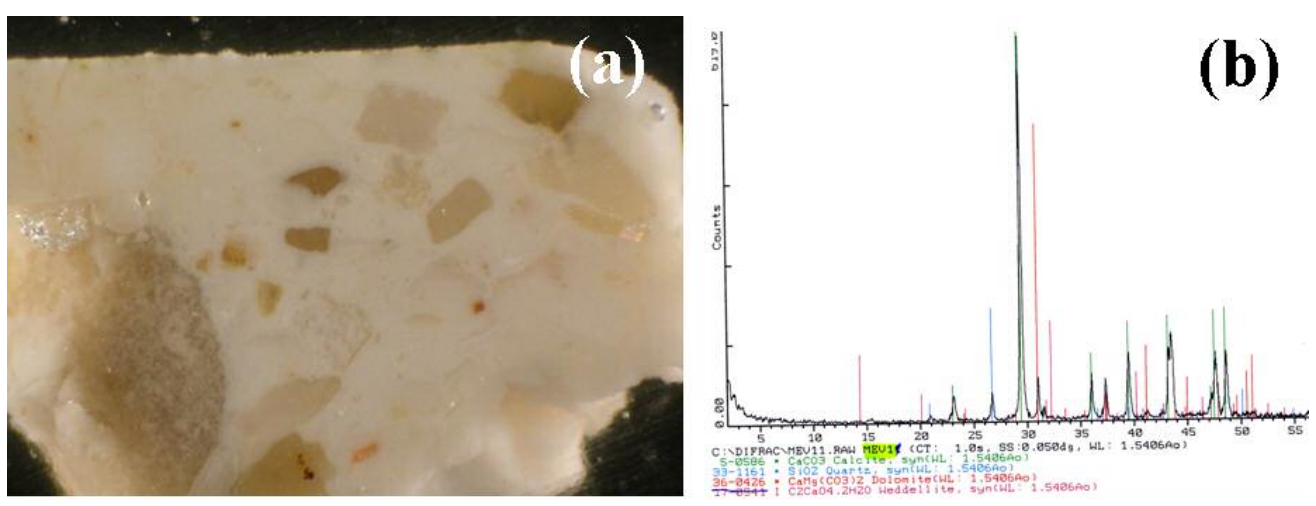

Selected optical micrograph of cross-section sample of mural painting from Mevku (a) with corresponding XRD diagram (b). 

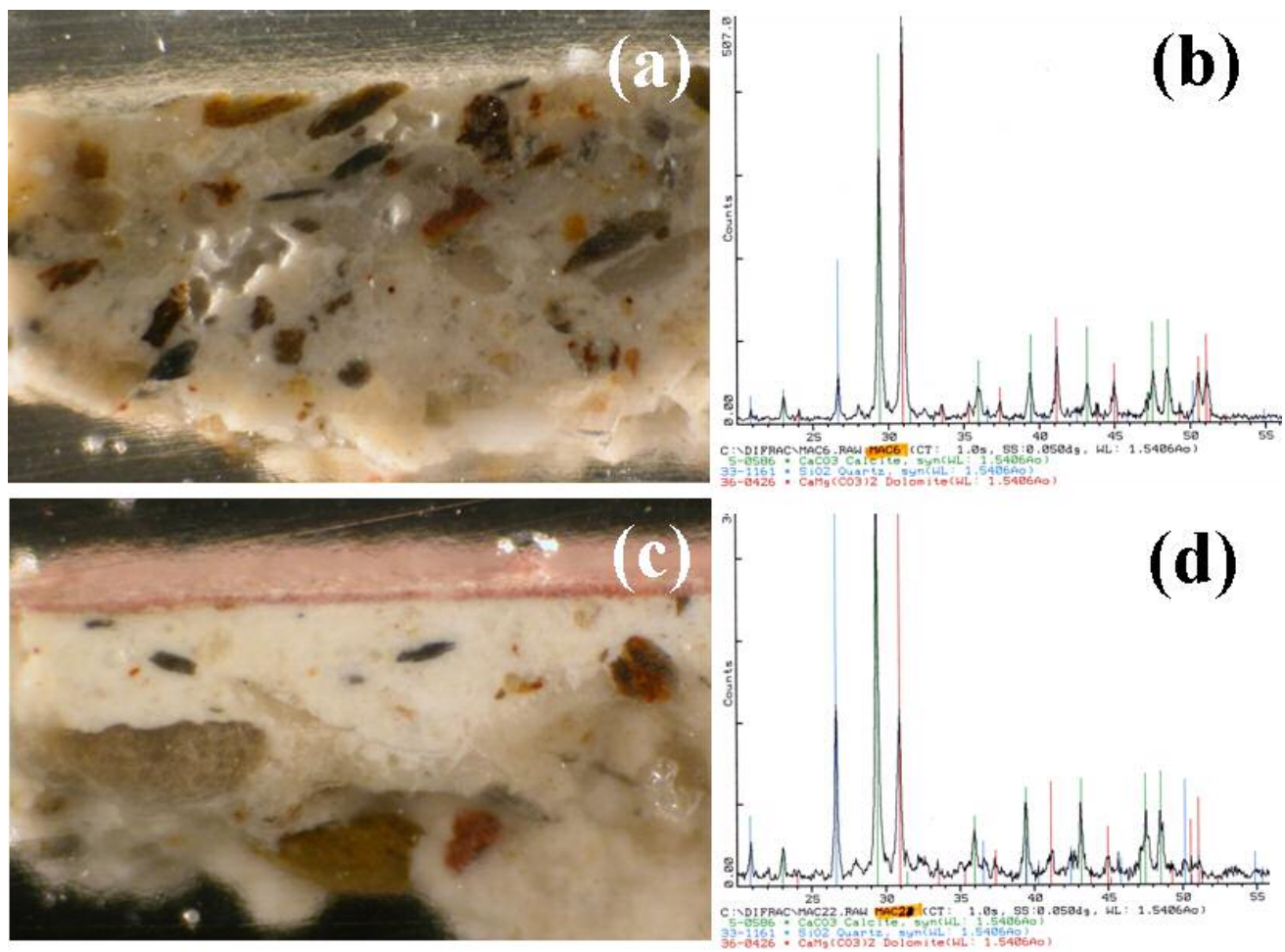

Selected optical micrograph of cross-section sample of mural painting from Mače. The outer mortar (a) with corresponding XRD diagram (b) and the inner mortar (c) with the corresponding XRD diagram (d). 

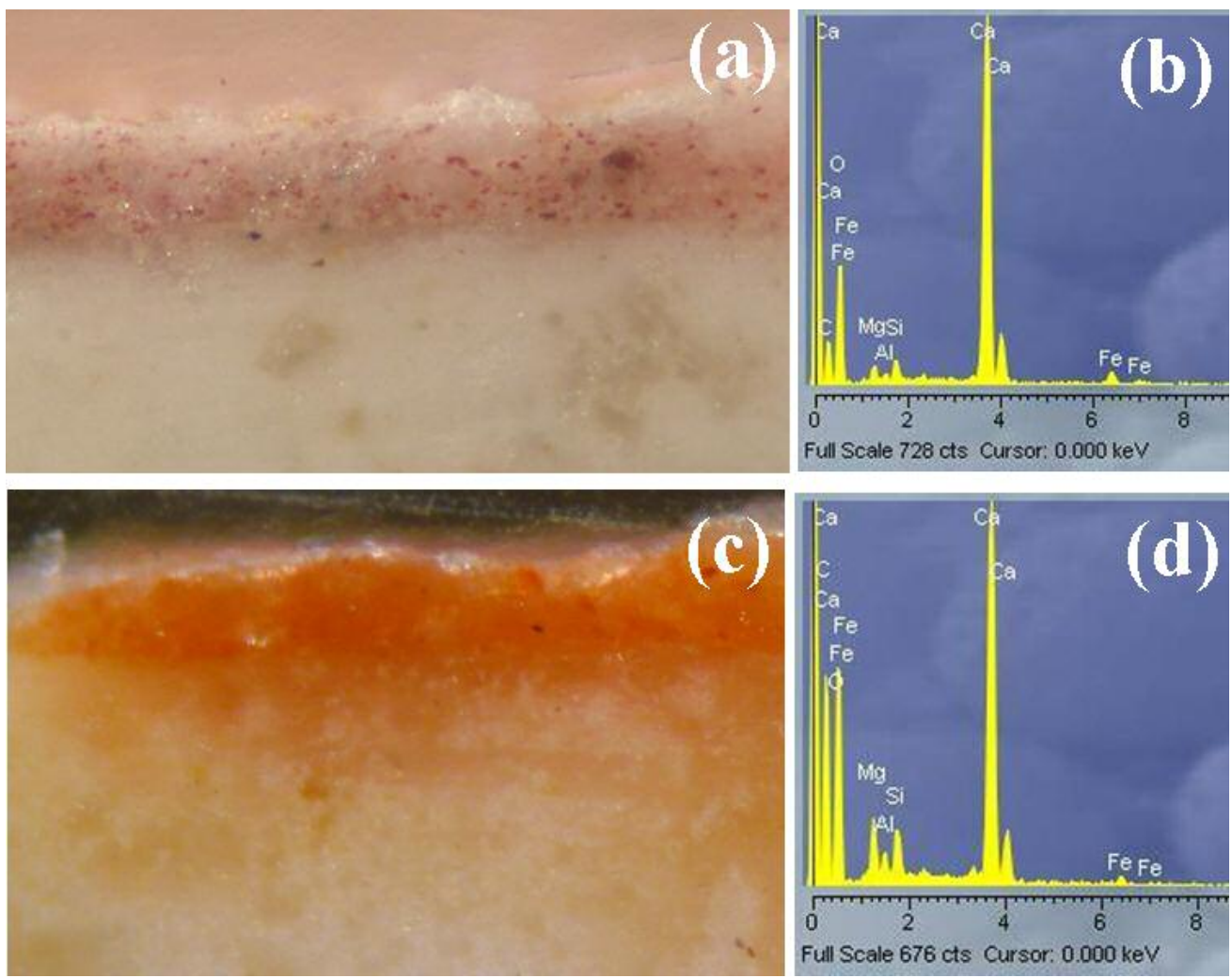

Selected optical micrographs of cross-section samples of mural paintings showing the violet colour made as a mixture of red ochre and white lime from Mače (a) with the corresponding EDX spectrum (b) and orange colour obtained by a mixture of yellow and red ochre from Mirna (c) with the corresponding EDX spectrum (d). 


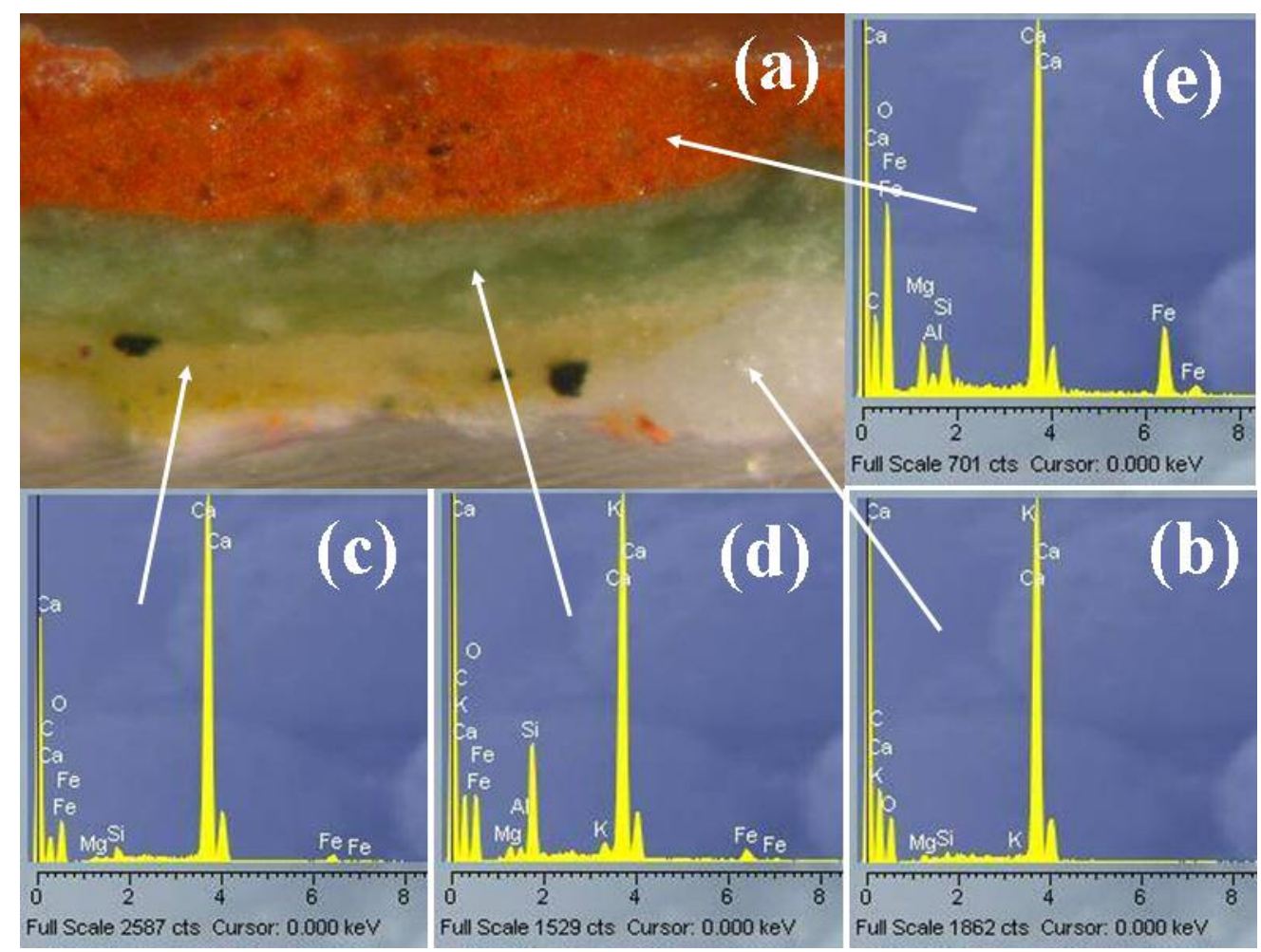

Selected optical micrograph of cross-section sample of mural painting from Mevku (a) with corresponding EDX spectra showing white lime (b), yellow ochre (c), green earth (d) and red ochre (e). 


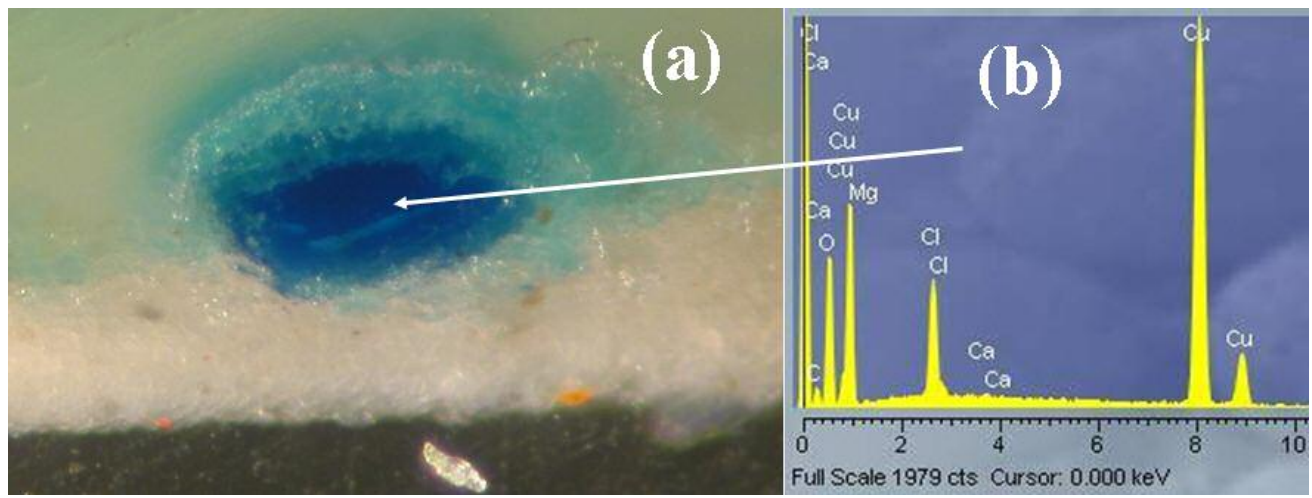

Selected optical micrographs of cross-section sample of mural painting from Mače (a) with corresponding EDX spectrum showing azurite. 


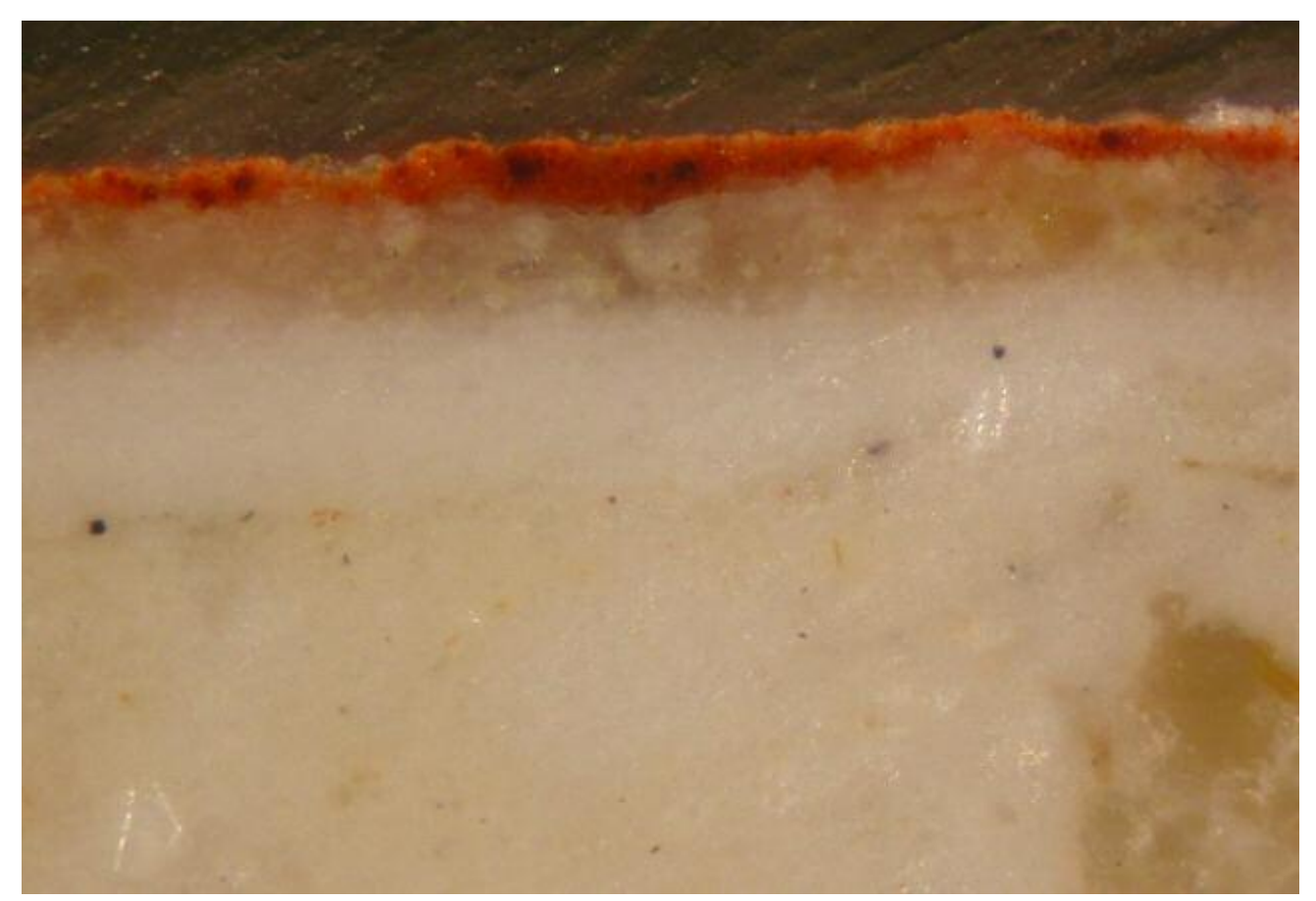

Selected optical micrograph of cross-section sample of mural painting in Crngrob showing the combination of lime technique and painting on a dry surface (a secco). 